\title{
The Impact of Environmental Management Plans on Firms' Compliance with Governmental Regulations and Environmental Laws
}

\author{
Hlamulo Makelane (Corresponding author) \\ Centre for Science, Technology and Innovation Indicators \\ (CeSTII), Human Sciences Research Council (HSRC) \\ Plein Park Building, 69-83 Plein Street, Cape Town, 8001, South Africa \\ Tel: 27-214-667-833Ｅ-mail: hrmakelane@hsrc.ac.za
}

Received: October 16, 2015 Accepted: November 6, 2015

doi:10.5296/emsd.v5i1.8402 URL: http://dx.doi.org/10.5296/emsd.v5i1.8402

\begin{abstract}
Many developed and developing countries have enacted environmental laws and regulations to control water quality and the environment. However, human activities, such as agriculture, urban and industrial development, mining, and recreation, significantly alter the quality of natural environments and their potential use. The compliance of firms with environmental laws is of great concern to scientists, governments, and regulatory agencies. The presence of hazardous chemicals in water resources even in small amounts may cause massive environmental damage. Thus, governments pass environmental laws and regulations to monitor human activity and enforce compliance with environmental standards. This study investigates the potential to improve firms' compliance with environmental standards by implementing an environmental management plan (EMP) within a public firm and a private firm in South Africa. EMP implementation is required to mitigate and manage environmental risk. This study asks the following research question: To what extent does EMP implementation enhance a firm's compliance to environmental laws and regulations? Further, to what extent are the specific characteristics of a firm associated with various EMP categories? The study used methods of inspection, observation, impact assessment, implementation, and monitoring to answer the research question. In both firms under study, the results showed no compliance with environmental law during initial site inspection and impact assessment. However, the implementation of EMPs in both firms improved compliance with environmental laws to nearly one hundred percent. As a result, EMPs were successfully implemented and monitored, improving the firms' compliance with
\end{abstract}


environmental laws and reducing negative environmental impacts to an insignificant level.

Keywords: Environmental law, Water quality, Inspection, Impact assessment, Environmental management plan

\section{Introduction}

Since the early 1970s, governments in developed and developing countries have amended or enacted a large number of environmental laws and regulations directed at limiting pollution of the natural environment (i.e., air, land and water) (Oosthuizen, 2002). Human activities - e.g., agriculture, urban and industrial development, mining, and recreation - significantly alter the quality of natural environments and environmental use potential. As such, governments put in place environmental laws and regulations in order to ensure compliance with environmental standards (Dasgupta, Laplante, Mamingi, \& Wang, 2001). Environmental protection and sustainable development policies aim to improve the level of compliance with national and international environmental laws by firms. However, there are few procedures available to accurately evaluate existing policies and strategies. Meanwhile, environmental and health quality continues to deteriorate (South Africa, Department of Environmental Affairs and Development Planning, 2008).

Access to safe drinking water is a major global problem requiring constant evaluation and revision of water policy at all levels (Hassan \& Sarma, 2013). One of the Millennium Development Goals (MDGs) is to halve the proportion of the population without sustainable access to safe drinking water (Statistics South Africa, 2010; OECD, 2010). South Africa is a signatory to the MDGs and thus aims to improve access to safe drinking water. However, the country's mining and manufacturing firms use significant amounts of water and contribute to high levels of wastewater pollution. Wastewater pollution, which occurs when pollutants are indirectly or directly discharged into bodies of water without adequate treatment to remove harmful compounds, affects plants and living organisms in rivers, seas, pipes, and canals (Tsuzuki, 2006, 2009).

Despite the adverse affects of wastewater pollution, many firms struggle to comply with environmental laws and regulations. According to the regulations, firms are required to internalize the costs of environmental externalities generated by them, which may reduce the competitiveness of compliant firms relative to non-compliant firms (Murty \& Kumar, 2003). Thus, levels of compliance to environmental regulations vary considerably across firms. Some firms do just enough to meet regulatory standards, some do less, and others do not comply at all. A natural question is why firms choose to violate regulations and what are the motivations behind the decisions firms make regarding compliance? Do a facility's characteristics or external factors determine the compliance level? The answers to these questions are important for a number of reasons, including the need for policy development to reduce environmental violations and encourage compliance. It is particularly crucial to understand the motivations of firms with regard to environmental compliance because environmental management has been touted as a powerful remedy to direct command-and-control regulations (Konar \& Cohen, 1997). 


\section{MlMacrothink}

Environmental Management and Sustainable Development

ISSN 2164-7682

2016, Vol. 5, No. 1

The South African government has enacted a number of environmental laws and regulations, including the National Water Act (South Africa, 1998a) and National Environmental Management Act (South Africa, 1998b), which aim to encourage environmental compliance among firms in the country (Papu-Zamxaka, Harpham, \& Mathee, 2010). Firms must receive an environmental authorization certification for environmental law compliance from a competent national authority. To obtain the certification, an authorized research institution has to conduct an assessment of the firm's activities to see whether they comply with or violate regulatory standards on waste management and environmental pollution (OECD, 2010; South Africa, Department of Environmental Affairs and Tourism, 2009). A number of factors affect the management of environmental impacts related to activities, structures, and infrastructure within the manufacturing, industrial, and other sectors (UNEP, 1997). First, organizations are increasingly being held responsible for environmental actions, as reflected by the growing number of laws, regulations, and penalties (Wu, 2009). Moreover, organizations are now obliged to measure, control, and disclose their environmental performance and conform to compliance standards in terms of environmental impact assessment regulations (Earnhart, \& Leonard, 2013). Second, a reliable environmental management plan (EMP) is necessary to supply information for decision-making, while ensuring environmental objectives are obtained (DEAT, 2004). EMPs provide systematic guidelines for enforcing and ensuring that actions are taken to minimize identified impacts (Lochner, 2005). Third, the allocation of limited resources towards environmental problem solving requires persuasive evidence supporting the benefits of such actions. The level and depth of information and resources contained in an EMP should reflect the level of activity-related environmental risk, while at the same time remaining practical and achievable (Lochner, 2005).

This study aims to investigate the potential to improve firms' compliance with environmental standards for water resources management by measuring the level of compliance before and after the implementation of an environmental management plan in a public firm and a private firm. Although no clear empirical evidence is available, this study contributes to providing evidence of the benefits of an EMP and its capacity to improve compliance. EMPs have increasingly become part of the conditions of approval for environmental compliance. A properly developed EMP is a key element in the sound management of environmental pollution (Peterson \& Diss-Torrance, 2012). An implemented EMP has the potential to manage impacts associated with various operations in the firms under study. The research also examines the association among firms' characteristics and dimensions, namely, the importance and use of measurement.

\section{The framework}

Preferences regarding environmental compliance by firms are affected by expected benefits compared to the cost associated with compliance. Business case studies and economic research findings suggest that firm managers' environmental attitudes, beliefs, and values are critical in shaping their environmental management efforts (Nakamura, Takahashi, \& Vertinsky, 2001). Firms facing regulatory environmental standards may choose to violate these standards or to comply by meeting the regulatory standards (Gangadharan, 2006). 
Environmental violations may entail direct costs, including penalties or fines imposed by governments. Costs may be an important determinant of a particular firm's level of compliance (Henri \& Journeault, 2008). Activities may differ in operation but often face the same regulations and are subject to the same penalties (Dasgupta, et al., 2001). Firms who do not comply may receive bad publicity, which may have implications on future cash flow, and investors may view a firm's environmental performance as a signal of production efficiency, good management practices, and reduced risk (Ding, 2008). To improve firms' compliance with standard regulations and to encourage them to avoid government penalties, environmental groups should prioritize targeted awareness programs to ensure that firms and their employees are aware of environmental laws and regulations. Meanwhile, governments can incentivize good behavior by presenting awards for compliance with environmental laws.

The process of establishing EMPs within firms should be transparent and serve as a working tool to improve levels of compliance and commitment across the management structure. The workforce is the most important element for success. Firms facing strong competition or regulatory pressure may benefit from good environmental performance.

For this study, the EMP simply suggested that firms could reach an improved compliance level by monitoring and measuring standard regulations. The EMP is recognized as a tool that can ensure that firms make suitable provision for environmental mitigation, and also describes the methods and procedures for mitigating and monitoring impacts with environmental objectives and targets (Bennett, Kemp, \& Hudson, 2016). The firms need to achieve its objectives and target in order to reduce or eliminate negative impacts. The EMP will be used throughout the firm's life cycle and updated regularly to align with the firm's progress in monitoring the environmental impact. The EMP outlines environmental impacts, mitigation measures, roles and responsibilities, timescales, and costs of mitigation. There is a need to demonstrate that EMPs can monitor and manage environmental impacts in order to improve compliance with environmental law.

The EMP under study is divided into three sections, namely:

1. Section one: The description of the environment, which describes the environmental settings of the study area;

2. Section two: Impact identification, which describes the environmental impacts associated with the study area;

3. Section three: Mitigation measures or specific environmental measures, procedures, and controls, which are relevant to the maintenance of various operational sites.

\section{Study Design}

\subsection{Brief Background of the Firm}

This study was carried out in two manufacturing firms, one public and the other private. This study was made possible by collaborating with an independent environmental consultants appointed by the firms to compile and integrated EMP and facilitate the process of environmental monitoring and auditing. The study took place over a two-year period, in order to adequately monitor the progress of the implemented EMPs. Due the nature of the firms' 
activities in electrical and mechanical product evaluation, maintenance, repairs, and reconstruction, it was of interest to evaluate these firms' levels of compliance to environmental laws. The firms' activities require them to maintain a chemical cleaning laboratory that generates wastewater and necessitates chemical drainage, which contributes to water pollution and results in high levels of wastewater pollution. As a result, the firms contribute to environmental water pollution and cause high levels of wastewater pollution. The levels of wastewater pollution and environmental compliance of both firms needed to be monitored.

\subsection{Data Collection}

This study applied the following data collection methods: inspection, observation, and taking photographs. The researcher chose a sample from a public firm and a private firm contributing to environmental pollution (air, water, and land) based on their reputation. Both firms had at least one hundred employees. These criteria ensured that the firms were large enough for organizational and strategic variables to apply and that management control systems were sufficiently developed. During inspection, the researcher asked the following questions selected from JunJie Wu's survey method (Wu, 2009):

1. What environmental issues are of significant concern to the facility?

2. What are one or two of the facility's most significant environmental concerns?

3. How many times was the facility inspected by an environmental agency during the past two years?

4. Who is responsible for the majority of environmental decision-making, including which environmental practices to implement?

5. What percentage of annual revenue is spent on environmental management?

\subsubsection{The Checklist}

During the inspection, the researcher used a checklist to ensure the inspection process covered all elements necessary to undertake a comprehensive of the firms' environmental practices. The checklist contents were as follows: date of inspection, number of participants, site and location of the firm, areas inspected, procedure of the inspection protocol, key findings and commentary, commentary on site tour, and photographs taken. All sections were carefully ticked off during the inspection. This helped in controlling for errors.

\subsubsection{Observation}

The study applied observation to conduct a situation analysis of the firms. The main purpose was to "see what was there and/or "what was not there", as well as the conditions of the surroundings. Similarly, the researcher observed the firms' activities.

\subsubsection{Photographs}

Photographs painted the clear picture of the situation within the firms. (Photos were taken after receiving approval from the firm management. 


\section{$\triangle$ Macrothink}

\subsection{Design, Identification, and Assessment}

\subsubsection{Inspection Design}

The researcher conducted an initial site inspection using impact and assessment methodology, in which the researcher asked questions and took pictures to analyze the current condition of environmental management within the firm. An impact can be defined as any change in the physical-chemical or socio-economic environmental system that can be attributed to human activities (Koundouri, Ker Rault, Pergamalis, Skianis, \& Souliotis, 2015; Uhlmann, Rifkin, Everingham, Head, \& May, 2014).

\subsubsection{Impact Identification}

The state of compliance to South African legislation on water pollution was determined in relation the National Environmental Management Act (South Africa, 2008; South Africa, 2014) and the National Water Act (South Africa, 1998a).

\subsubsection{Impact Assessment}

The criteria for the description and assessment of environmental impacts were drawn from regulations in a guidelines document published by the South African Department of Environmental Affairs and Tourism (2009). The detailed levels were determined by assigning a specific value to each impact. In order to establish a coherent framework within which all impacts could be objectively addressed, it was necessary to establish a rating system, which was applied consistently to all the criteria. For such purposes, each impact was assigned a value ranging from one (1) to four (4), depending on its definition (Table 1). The impact assessment was determined through a synthesis of criteria: extent/scale, intensity/severity, and significance. It was noted that an impact could occur for any length of time during the life cycle of a firm's activities and not at any given time. A criterion was considered significant if it was very important in terms of both physical extent and time scale and was applied during the inspection in the framework of each firm's facilities. Therefore, the level of significance expressed through qualitative values was used to indicate the level of mitigation required and the measures of mitigation to be considered in the planning phase for the EMP.

Table 1. Impact assessment criteria for key environmental issues

\begin{tabular}{|l|l|c|}
\hline Description & Explanation & $\begin{array}{l}\text { Numerical } \\
\text { Value }\end{array}$ \\
\hline Extent/Scale & & 1 \\
\hline Site: & The impact affected the whole or a measurable portion of water quality & 2 \\
\hline Local: & The impacted area extends as far as the activity is concerned & 3 \\
\hline Regional: & The impact affected the area including neighboring areas & 1 \\
\hline Intensity/severity & & $\begin{array}{l}\text { The impact is non-existent or unsubstantial and of no or little importance to } \\
\text { any stakeholder }\end{array}$ \\
\hline Negligible: & $\begin{array}{l}\text { The impact alters the affected environment in such a way that natural } \\
\text { processes are not affected }\end{array}$ & 2 \\
\hline
\end{tabular}




\begin{tabular}{|c|c|c|}
\hline Moderate: & $\begin{array}{l}\text { The affected environment is altered, but functions and processes continue in } \\
\text { a modified way }\end{array}$ & 3 \\
\hline High: & $\begin{array}{l}\text { Function or process of the affected environment are disturbed to the extent of } \\
\text { temporarily or permanently ceasing }\end{array}$ & 4 \\
\hline \multicolumn{3}{|l|}{ Significance } \\
\hline Negligible: & $\begin{array}{l}\text { The impact is non-existent or unsubstantial and of no or little importance to } \\
\text { any stakeholder }\end{array}$ & 1 \\
\hline Low: & $\begin{array}{l}\text { The impact is limited in extent with low to medium intensity; whatever its } \\
\text { probability of occurrence was, the impact was not affecting the material and } \\
\text { was likely to require management intervention with increased costs }\end{array}$ & 2 \\
\hline Moderate: & $\begin{array}{l}\text { The impact was of importance to one or more stakeholders, and its intensity } \\
\text { is medium or high; therefore, the impact materially affected the decisions, } \\
\text { and management intervention is required }\end{array}$ & 3 \\
\hline High: & $\begin{array}{l}\text { The impact rendered development outcomes controversial, or the firms' } \\
\text { activities cannot be reduced to acceptable levels; and/or the cost of } \\
\text { management intervention is a significant factor in decision-making }\end{array}$ & 4 \\
\hline
\end{tabular}

Note: Extent assessment criteria refers to the physical and spatial size of the impact measured through numerical values; intensity/severity refers to the intensity of the impact considered by examining whether the impact is destructive or benign, whether it destroys the impacted environment, alters its functioning, or slightly alters the environment itself; and significance indicates the importance of the impact in terms of both physical and time scale with a level of mitigation required.

\section{Results and discussion}

Although the two firms differ in many activities, the applying environmental laws for water quality are the same. The baseline information obtained serves as a reference point for scientifically measuring and professionally judging future changes of the facility or site. The researcher gathered baseline information from the proposed firms through visual site inspection. According to the inspection's environmental management assessment on the probability of compliance from both firms, neither firm complied with environmental laws and standards for water quality with regard to the environmental impacts identified during the initial site inspection.

The firms' environmental management divisions were not aware of the environmental issues concerning their facilities. This made it difficult for them to list their most significant environmental concern. In both firms no inspection of the facilities had been conducted in many years, leading to most of the activities not being standardized or implemented according to the environmental legislation. Neither firm had assigned someone to be responsible for the majority of environmental decisions; hence implementing environmental practices was not possible. Neither firm had records of annual revenue spent on environmental management. As a result, it was impossible for firms to comply with environmental standards and regulations. The information obtained by asking the questions was supported by the criteria for the inspection framework, which included observation and taking photographs. During inspection, the main water resources management problems were identified as follows: 


\subsection{Storm Water Management}

Storm water systems require the presence of structures and infrastructure, which include roads and buildings designated to the same slope and orientation level as the natural slope, to allow free movement of storm water (de Lima, Singh, \& de Lima, 2003). In both firms, a formal storm water management system consisting of side drains was identified throughout the sites; however, some were blocked by domestic wastewater from the materials used on the facilities. During inspection, the firms altered the structures and infrastructure on the sites by modifying the low-lying areas to satisfy activities taking place. These in turn increased the natural flow of the storm water and acted as a storm water management channel. Pollution of storm water channels may have adverse impacts on the water quality of a site stream, and these can also have an impact downstream and on interconnected tributaries (Minchin, 2007). Furthermore, storm water runoff comprised of different substances with different hazard potential macro-pollution has a higher concentration of major-ions with lower concentration of trace elements (Minchin, 2007; Willems, 2001). Firms ignoring storm movement may considerably overestimate or underestimate runoff volume and associated soil loss by sheet erosion due to the interrelation between rainfall and runoff (de Lima, Singh, \& de Lima, 2003). Moving storms and the distribution of rainfall intensity in space and time are continuously changing (Göbel, Dierkes, \& Coldewey, 2007; Willems, 2013). Firms need to establish and monitor their outlet points in relation to on-site rivers. Impervious surfaces-such as roads, rooftops and parking areas - need to be minimized by designing roads using various permeable pavements, and installing green roofs or rainwater catchment systems (Peixe, Silva, Silva, \& Formiga-Johnsson, 2011). By minimizing impervious surfaces, remaining runoff could be managed and directed to bio-retention areas (or rain gardens). The introduction of amended soil, native vegetation, or other types of infiltration areas would improve storm water movement.

\subsection{Surface and Groundwater Management}

During inspection surface water was identified in both firms. Surface water includes runoff water or standing water that remains after precipitation, as well as storm water, which runs through on-site storm water drainage systems. In order to describe the quality of surface water on site, the surface water categories were assessed. The pavement surface throughout the entire site stimulates runoff and directs all the runoff water into the sea outlet in the public firm and to the river in the private firm. However, surface pollution had taken place in the form of oil spillages (Fig.1) running through surface drains connected to the storm water channels, littering, and waste oil from chemical lab and oil storages. A higher concentration of hydrochloric acid $(\mathrm{HCl})$ was detected in the chemical wastewater coming out of the chemical cleaning laboratory. This water runs through the drain. During the inspection, there were no measures in place or records of disposal methods used to transfer chemical wastewater to a hazardous waste site. The fact that the chemical wastewater runs through an open drain was observed to be a safety risk to employees or other people that may come into contact with it. The image below shows oil spillages that flow through the surface drain into the storm water channels. The standing water observed in both firms occurred as a result of poor surface aeration or storm water management. 


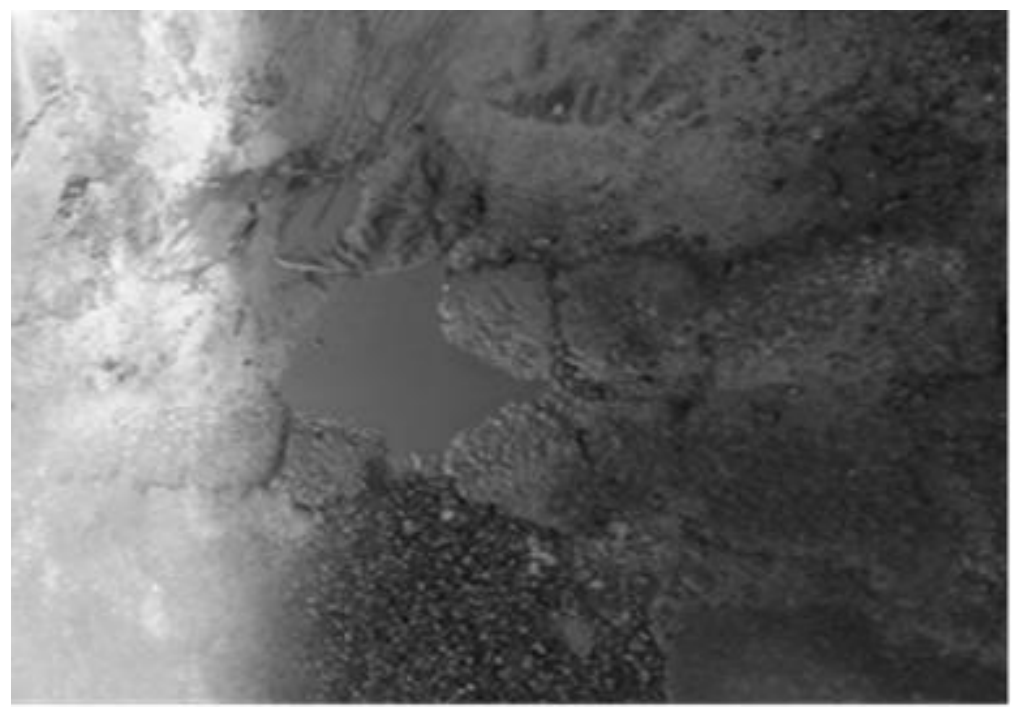

Figure 1. The oil spillages that flow through the surface drain into the storm water channels

The image below shows standing water forming swampy conditions (Fig. 2). This results from a surface orientation or slope angel that does not stimulate runoff into the storm water drain. With regard to groundwater, the researcher recommended that the firms undertake a sampling and monitoring process to assess on-site groundwater levels and quality. During the site inspection, firms were not complying with the regulation. Identified groundwater should be used for ongoing monitoring; this will be a useful indicator of local groundwater quality. In addition, wastewater running through an underground drain released a chemical odor when assessed during the inspection. This could be attributed to this water's chemical properties. The drain runs into the adjacent sea outlet, which poses a threat to marine animals, and also discharged into the river outlet. While it is understood that the surface wastewater can be filtered through the fat trap before entering the drain for ultimate disposal into the watercourse, during the inspection the quality of the filtered water was not up to standard, and it needed a replacement. The filter was very old and did not comply with the South African National Water Act for discharging waste or water containing waste into a water resource through a pipe, canal, sewer, sea outfall, or other conduit. The poor filter quality of the water may also pose a health and safety risk to firm employees, and contaminated products from wastewater use area may subsequently affect humans, though secondary human contamination, or animals, through consumption and plants on the site. It may become visually displeasing, particularly if it contains detergents and components that may attract flies. On the other hand, wastewater irrigation can increase the available water supply or release better quality supplies for alternative uses on-site or nearby. The researcher sampled the underground and surface water, and designed mitigation measures according to the proposed management's EMP. 


\section{Macrothink}

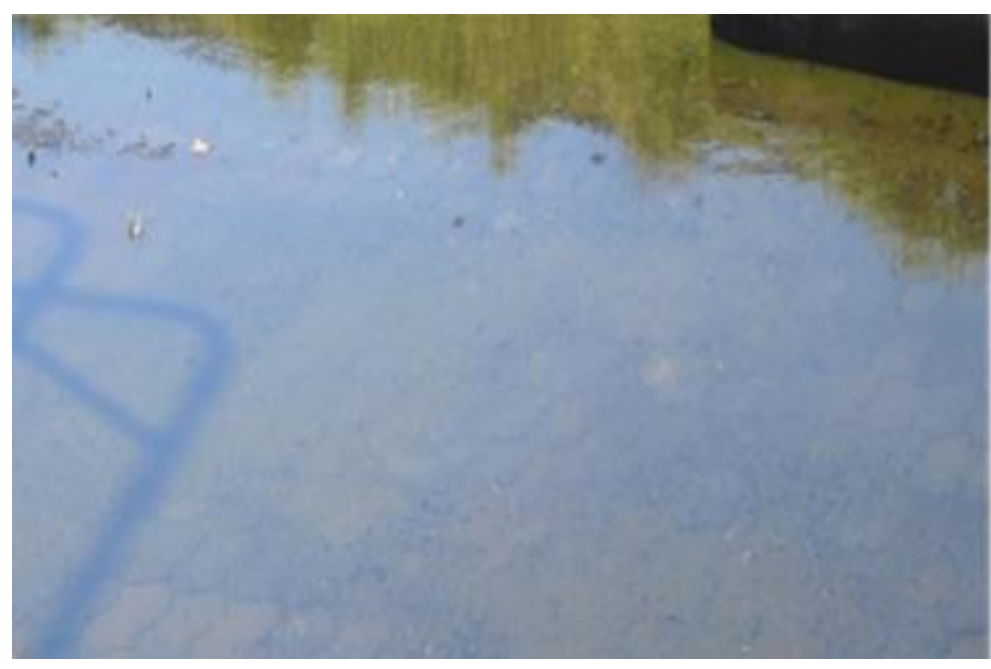

Figure 2. The standing water forming swampy conditions

\subsection{Water Resource Impact Assessment}

The rating criteria and numeral values were assigned to each impact observed from waste, storm, surface, and groundwater management to describe its significance of aspect/activity at the time of inspection. From the observed and discussed results above, the significant assessment criteria and the water resource levels were recorded. Table 2 shows the results obtain from the impact assessment. The extent/scale identified for storm water, was found to have an impact on the site for public firm, and the impact affected the measurable portion of water quality and for private firm, the impacted area extends as far as the activity is concerned. The identified intensity or severity had a low impact on natural processes, however, other impacts affected the environment, but functions and processes continue in a modified way. Other processes were found to be disturbed to an extent, and mitigation was to be considered in both firms. Significantly, the level of mitigation required as identified during the assessment was moderate (its intensity was medium or high) and required intervention. For surface and groundwater impact assessment, the assessment identified the extent/scale, which had a low impact on the site; however, it had a moderate impact with numerical value of three (3) for public firm and low impact for private firm, in terms of intensity or severity. In terms of significance, the impact assessment identified a low impact on natural processes for private firm and moderate impact for public firm. Similarly, in wastewater moderate impacts were observed, and other processes were found to be disturbed to an extent in terms of management and monitoring the impact in detail. The level of mitigation required was also very significant in both firms.

Table 2. Impact assessment of waste, surface, storm, and groundwater identified during inspection for both firms

\begin{tabular}{|l|l|l|l|l|l|l|l|}
\hline \multirow{2}{*}{ Impact } & \multicolumn{3}{|l|}{ Public firm } & \multicolumn{2}{l|}{ Private firm } \\
\cline { 3 - 8 } & Aspect/Activity & $\begin{array}{l}\text { Extent/ } \\
\text { Scale }\end{array}$ & $\begin{array}{l}\text { Intensity/s } \\
\text { everity }\end{array}$ & Significance & $\begin{array}{l}\text { Extent/ } \\
\text { Scale }\end{array}$ & $\begin{array}{l}\text { Intensity/s } \\
\text { everity }\end{array}$ & Significance \\
\hline Wastewater & $\begin{array}{l}\text { Disposal of } \\
\text { effluents and }\end{array}$ & 2 & 3 & 3 & 1 & 3 & 3 \\
\hline
\end{tabular}




\section{Macrothink}

\begin{tabular}{|l|l|l|l|l|l|l|l|}
\hline & $\begin{array}{l}\text { polluted } \\
\text { wastewater }\end{array}$ & & & & \\
\hline $\begin{array}{l}\text { Surface and } \\
\text { groundwater } \\
\text { water, leakages of } \\
\text { underground septic } \\
\text { tanks, and oil } \\
\text { spillages running } \\
\text { through surface } \\
\text { drains }\end{array}$ & 1 & 3 & 3 & 1 & 2 & 2 \\
\hline Storm water & $\begin{array}{l}\text { Polluted } \\
\text { wastewater through } \\
\text { storm water } \\
\text { drains/channels, } \\
\text { monitor oil/fuel } \\
\text { spillages }\end{array}$ & 1 & 3 & 3 & 2 & 3 & 3 \\
\hline
\end{tabular}

Note: Numerical values are defined under Table 1.

\subsection{Environmental Management Plan Implementation Process}

As revealed by the impact assessment, both firms had less than fifty percent compliance, namely, twenty-five and thirty percent compliance, indicating a need in both firms to implement an EMP (Table 3). In proposing EMP strategies, care was given to the fact that the affected site facilities comprise a diverse environment with distinguished environmental impacts, which therefore requires a focused approach to effectively manage and control. In both firms a huge cause of environmental degradation was a lack of centralized responsibility and accountability for environmental management actions. Therefore, this study proposed a focused or divisional approach to environmental management within the firms' environmental department. The water resource environment representing water bodies and on-site water resources needs to be monitored on a regular basis. The firms have to assign someone to be responsible for monitoring all water sources in the facility including storm water, groundwater, surface water, and wastewater. This was to ensure effective and unit-specific management of environmental impacts and improve compliance with environmental standard and regulations.

\subsection{Monitoring Process}

The impacts and aspects of non-compliance in terms of statutory legislations of the National Environmental Management Act (Act 107 of 1998) and other legislations of local and national application were identified. These impacts included wastewater, surface water, storm water, and groundwater management. Mitigation measures to ensure that such activities conform to compliance standards given in terms of the environmental impact assessment regulations (EIA) regulations. Compliance with all legal and regulatory requirements was taken into consideration during EMP development. The EMP acted as systematic guideline to both enforce and ensure that remedial actions were taken to minimize identified impacts. Based on the compliance with the EMP conditions, a quarterly environmental monitoring 


\section{Macrothink}

Environmental Management and Sustainable Development

ISSN 2164-7682 2016, Vol. 5, No. 1

process was conducted using the monitoring scoring system in Appendix 2. Each firm conducted a quarterly environmental monitoring process using the EMP with environmental compliance solutions to the impacts (Appendix 1). The monitoring system for EMP development was completed in terms of information obtained. As indicated in Table 3, within six months, or in the second quarter, of implementing and monitoring the EMP, both firms had improved their compliance levels from twenty-five to thirty percent to at least sixty percent. After twelve months of EMP implementation and monitoring, the compliance level in both firms moved from twenty-five and thirty to almost one hundred percent (Table 3). This shows that the implementation of a good EMP for compliance with environmental laws and regulations can improve firms' compliance levels if firms implement and monitor such a document. The EMP was implemented with the sole aim of providing corrective actions to improve compliance through the application of environmental compliance solutions (e.g., prohibiting use of dangerous chemicals and hazardous materials, assessing groundwater pollution, etc.). Although the firms' achieved environmental compliance of their operational functions, it was critical for the firms' to ensure proper environmental management and improve overall operational management. The firms can reduce or avoid environmental impacts by applying EMP strategies with the assistance of their respective chief executive officers and safety, health, environment and quality managers, taking into account the state of water quality in each firm.

Table 3. Monitoring for key environmental issues

\begin{tabular}{|c|c|c|c|c|c|}
\hline Impact & Aspect/Activity & $\begin{array}{l}\text { Compliance at the } \\
\text { time of } \\
\text { environmental } \\
\text { assessment: }\end{array}$ & $\begin{array}{l}\% \text { Compliance } \\
\text { before EMP: }\end{array}$ & $\begin{array}{l}\% \text { Compliance } \\
\text { after EMP: } \\
(6 \text { months })\end{array}$ & $\begin{array}{l}\% \text { Compliance } \\
\text { after EMP: } \\
(12 \text { months })\end{array}$ \\
\hline Wastewater & $\begin{array}{l}\text { Disposal of effluents and } \\
\text { polluted wastewater }\end{array}$ & $\mathrm{X}$ & $30 \%$ & $60 \%$ & $85 \%$ \\
\hline $\begin{array}{l}\text { Surface and } \\
\text { groundwater }\end{array}$ & $\begin{array}{l}\text { Monitor: standing water, } \\
\text { leakages of underground } \\
\text { septic tanks, and oil } \\
\text { spillages running through } \\
\text { surface drains }\end{array}$ & $\mathrm{X}$ & $25 \%$ & $65 \%$ & $85 \%$ \\
\hline Storm water & $\begin{array}{l}\text { Polluted wastewater } \\
\text { through storm water } \\
\text { drains/channels, monitor } \\
\text { oil/fuel spillages }\end{array}$ & $\mathrm{X}$ & $30 \%$ & $55 \%$ & $75 \%$ \\
\hline
\end{tabular}

\section{Conclusion}

The findings revealed that at the time of the initial inspection and assessment, neither firm was compliant with environmental laws concerning water quality. Governance strategies for environmental law should take into account that both firms were non-compliant. Site inspection and impact assessment was followed by the successful implementation of an EMP to monitor compliance in both firms and reduce the identified impacts to an insignificant 
level. Following the EMP implementation, both firms improved their level of compliance with environmental laws relating to water quality from non-compliant to a level of compliance reaching almost one hundred percent. It is equally important to conduct annual inspections to ensure that regulations are correctly followed. This study provides a foundation on which to improve environmental compliance in the country. It is clear that South African firms could comply with environmental laws if EMPs are used to monitor their compliance levels. EMP implementation can assist in adjusting environmental standards and regulations accordingly by local and national governance for water quality, water resources, and environmental management.

\section{References}

Bennett, S., Kemp, S., \& Hudson, M. D. (2016). Stakeholder perceptions of Environmental Management Plans as an environmental protection tool for major developments in the UK. Environmental Impact Assessment $\quad$ Review. 56.71. http://doi.org/10.1016/j.eiar.2015.09.005

Dasgupta, S., Laplante, B., Mamingi, N., \& Wang, H. (2001). Inspections, pollution prices, and environmental performance: evidence from China. Ecological Economics. 36(3). 487-498. http://doi.org/10.1016/S0921-8009(00)00249-4

de Lima, J. L. M., Singh, V. P., \& de Lima, M. I. P. (2003). The influence of storm movement on water erosion: storm direction and velocity effects. Catena. 52(1). 39-56. http://doi.org/10.1016/S0341-8162(02)00149-2

DEAT (Department of Environmental Affairs and Tourism) (2004). Environmental Management Plans, Integrated Environmental Management, Information series 12. [Online] Available: https://www.environment.gov.za.

Ding, G. K. C. (2008). Sustainable construction - the role of environmental assessment tools. Journal of Environmental Management. 86(3). 451-64. http://doi.org/10.1016/j.jenvman.2006.12.025

Earnhart, D., \& Leonard, J. M. (2013). Determinants of environmental audit frequency: the role of firm organizational structure. Journal of Environmental Management. 128. 497-513. http://doi.org/10.1016/j.jenvman.2013.05.042

Gangadharan, L. (2006). Environmental compliance by firms in the manufacturing sector in Mexico. Ecological Economics. 577-486. http://doi.org/10.1016/j.ecolecon.2005.10.023

Göbel, P., Dierkes, C., \& Coldewey, W. G. (2007). Storm water runoff concentration matrix for urban areas. Journal of Contaminant Hydrology. 91(1-2). 26-42. http://doi.org/10.1016/j.jconhyd.2006.08.008

Hassan, Y., \& Sarma, H. P. (2013). Road Runoff Water Pollution in the Urban Environment of Guwahati City. Electronic Journal of Chemistry. 1(2). 34-43. [Online] Available: www.mutagens.co.in/ejchem 
Henri, J.-F. \& Journeault, M. (2008). Environmental performance indicators: an empirical study of Canadian manufacturing firms. Journal of Environmental Management. 87(1). 165-76. http://doi.org/10.1016/j.jenvman.2007.01.009

Konar, S., \& Cohen M. A. (1997). Information As Regulation: The Effect of Community Right to Know Laws on Toxic Emissions. Journal of Environmental Economics and Management. 32(1). 109-124. http://doi.org/10.1006/jeem.1996.0955

Koundouri, P., Ker Rault, P., Pergamalis, V., Skianis, V., \& Souliotis, I. (2015). Development of an integrated methodology for the sustainable environmental and socio-economic management of river ecosystems. Science of The Total Environment. 540. 90-100. http://doi.org/10.1016/j.scitotenv.2015.07.082

Lochner, P. (2005). Guideline for Environmental Management Plans. CSIR Report No. ENV-S-C. 2005-053 H. Republic of South Africa, Provincial Government of the Western Cape, Department of Environmental Affairs and Development Planning, Cape Town. [Online] Available: https://westerncape.gov.za.

Minchin, D. (2007). Aquaculture and transport in a changing environment: overlap and links in the spread of alien biota. Marine Pollution Bulletin. 55(7-9). 302-13. http://doi.org/10.1016/j.marpolbul.2006.11.017

Murty, M. N., \& Kumar, S. (2003). Win-win opportunities and environmental regulation: testing of porter hypothesis for Indian manufacturing industries. Journal of Environmental Management. 67(2). 139-144. http://doi.org/10.1016/S0301-4797(02)00203-7

Nakamura, M., Takahashi, T., \& Vertinsky, I. (2001). Why Japanese Firms Choose to Certify: A Study of Managerial Responses to Environmental Issues. Journal of Environmental Economics and Management. 42(1). 23-52. http://doi.org/10.1006/jeem.2000.1148

OECD (Organization for Economic Cooperation and Development) (2010). Improving the Effectiveness and Efficiency of Environmental Inspections: Risk-based Prioritisation and planning in Moldova. [Online] Available: http://www.oecd.org.

Oosthuizen, L. K. (2002). Land and water resources management in South Africa. [Online] Available: http://afeid.montpellier.cemagref.fr/old/ILWRM/Sacase.pdf.

Papu-Zamxaka, V., Harpham, T., \& Mathee, A. (2010). Environmental legislation and contamination: the gap between theory and reality in South Africa. Journal of Environmental Management. 91(11). 2275-80. http://doi.org/10.1016/j.jenvman.2010.06.014

Peixe, C., Silva, L. P., Silva, W. A., \& Formiga-Johnsson, R. (2011). Rainwater Harvesting for Sustainable Drainage and Non Potable Use in the Schools of Rio de Janeiro, Brazil. 12th International Conference on Urban Drainage, Porto Alegre, Brazil, 10-15 September 2011.

Peterson, K., \& Diss-Torrance, A. (2012). Motivation for compliance with environmental regulations related to forest health. Journal of Environmental Management. 112. 104-19. http://doi.org/10.1016/j.jenvman.2012.06.023 
South Africa (1998a). National Water Act [Act No. 36 of 1998]. [Online] Available: https://www.dwa.gov.za.South Africa, Department of Environmental Affairs and Development Planning, Western Cape (2008). A climate change strategy and action plan for the Western Cape. [Online] Available: http://www.capegateway.gov.za/eadp.

South Africa (1998b). National Environmental Management Laws Amendment Act [Act No 107 of 1998]. [Online] Available: https://www.environment.gov.za.

South Africa (2008). National Environmental Management Amendment Act [Act No. 62 of 2008. [Online] Available: https://www.environment.gov.za.

South Africa. (2014). National Environmental Management Laws Amendment Act [Act No. 25 of 2014]. [Online] Available: https://www.environment.gov.za.

South Africa, Department of Environmental Affairs and Tourism (2009). Fifteen years: A review of the Department of Environmental Affair and Tourism. [Online] Available: https://www.environment.gov.za.

Statistics South Africa (2010). Millennium Development Goals: Country Report. 1-139. [Online] Available: http://www.statssa.gov.za/MDG/MDGR_2010.pdf.

Tsuzuki, Y. (2006). An index directly indicates land-based pollutant load contributions of domestic wastewater to the water pollution and its application. Science of the Total Environment. 370(2-3). 425-40. http://doi.org/10.1016/j.scitotenv.2006.07.014

Tsuzuki, Y. (2009). Corrigendum to the abstract of Tsuzuki, Y. An index directly indicates land-based pollutant load contributions of domestic wastewater to the water pollution and its application. Science of the Total Environment. 370(2-3). 425-440. http://doi.org/10.1016/j.scitotenv.2009.04.024

Uhlmann, V., Rifkin, W., Everingham, J.-A., Head, B., \& May, K. (2014). Prioritising indicators of cumulative socio-economic impacts to characterise rapid development of onshore gas resources. The Extractive Industries and Society. 1(2). 189-199. http://doi.org/http://dx.doi.org/10.1016/j.exis.2014.06.001

UNEP (United Nations Environmental Programme) (1997). Environmental management in oil and gas exploration and production. [Online] Available: http://www.ogp.org.uk/pubs/254.pdf

Willems, P. (2001). A spatial rainfall generator for small spatial scales. Journal of Hydrology. 252(1-4). 126-144. http://doi.org/10.1016/S0022-1694(01)00446-2

Willems, P. (2013). Revision of urban drainage design rules after assessment of climate change impacts on precipitation extremes at Uccle, Belgium. Journal of Hydrology. 496. 166-177. http://doi.org/10.1016/j.jhydrol.2013.05.037

Wu, J. (2009). Environmental compliance: The good, the bad, and the super green. Journal of Environmental Management. 90(11). 3363-81. http://doi.org/10.1016/j.jenvman.2009.05.017 


\section{Macrothink \\ Environmental Management and Sustainable Development \\ ISSN 2164-7682 \\ 2016, Vol. 5, No. 1}

\section{Appendix}

Appendix 1. Environmental compliance solutions to the impact management

\begin{tabular}{|c|c|c|}
\hline Impact & Aspect/Activity & Environmental compliance solutions: \\
\hline Wastewater & $\begin{array}{l}\text { Disposal of effluents and polluted } \\
\text { wastewater }\end{array}$ & $\begin{array}{l}\text { Wastewater was disconnected from } \\
\text { the storm water drain and channeled } \\
\text { in to a holding sump } \\
\text { The use of dangerous chemicals and } \\
\text { hazardous substances along with } \\
\text { water disposed off into streams was } \\
\text { prohibited. } \\
\text { Laboratory testing of a filtered water } \\
\text { sample was tested in order to } \\
\text { determine whether the discharged } \\
\text { water constitute wastewater }\end{array}$ \\
\hline $\begin{array}{l}\text { Surface \& } \\
\text { groundwater; }\end{array}$ & $\begin{array}{l}\text { Monitor: standing water, leakages } \\
\text { of underground septic tanks, and } \\
\text { oil spillages running through } \\
\text { surface drains }\end{array}$ & $\begin{array}{l}\text { An Assessment of pollution of the } \\
\text { Groundwater regime was conducted } \\
\text { Regular monitoring of handling } \\
\text { facilities was conducted to ensure that } \\
\text { there is no leakage }\end{array}$ \\
\hline Storm water & $\begin{array}{l}\text { Polluted wastewater through storm } \\
\text { water drains/channels, monitor } \\
\text { oil/fuel spillages }\end{array}$ & $\begin{array}{l}\text { All chemical drains were disposing } \\
\text { off into a holding sump and was } \\
\text { disconnected from the storm water } \\
\text { drain. }\end{array}$ \\
\hline
\end{tabular}

National legislation concerning water resources:

- National Environmental Management, 1998 (Act No 107 of 1998)

- National Water Act, 1998 (Act No 36 of 1998)

- Department of Water Affairs and Forestry Policy on the waste in terms of Section 20 of the Environment Conservation Act, 1989 (Act 73 of 1989)

- Department of Water Affairs and Forestry Guideline on Process 39: Waste Incineration Process 


\section{Macrothink \\ Environmental Management and Sustainable Development \\ ISSN 2164-7682 \\ 2016, Vol. 5, No. 1}

Appendix 2. Environmental scoring checklist

\begin{tabular}{|l|l|}
\hline Issues & Water resources management \\
\hline$\sqrt{ }$ & Compliance is from 51\% to $100 \%$ \\
\hline Maximum Score & Non-compliance $<50 \%$ \\
& $\begin{array}{l}\text { Quality of Compliance: } \\
\text { 1. Very low significance } \\
\text { 2. Low significance } \\
\text { 3. Medium significance } \\
\text { 4. High significance }\end{array}$ \\
\hline Rating & Points allocated out of the maximum score \\
\hline Comments & Concerns associated with non-compliance with the EMP \\
\hline
\end{tabular}

\section{Copyright Disclaimer}

Copyright for this article is retained by the author(s), with first publication rights granted to the journal.

This is an open-access article distributed under the terms and conditions of the Creative Commons Attribution license (http://creativecommons.org/licenses/by/3.0/). 